\title{
Perbedaan Perhitungan Unit Cost dengan Menggunakan Metode Activity Based Costing (ABC) dan Metode Doubel Distribution (DD) untuk Pasien Tb Paru Kategori 2 di Instalasi Rawat Jalan dan Rawat Inap Rumah Sakit Paru
}

\author{
Lukman Hilfi ${ }^{1}$, Elsa Pudji Setiawati ${ }^{1}$, Henni Djuhaeni ${ }^{1}$, Sekar Ayu Paramita ${ }^{1}$, Ratna Komara ${ }^{2}$ \\ ${ }^{1}$ Departemen Ilmu Kesehatan Masyarakat Fakultas Kedokteran Universitas Padjadjaran \\ ${ }^{2}$ Fakultas Ekonomi dan Bisnis Universitas Padjadjaran
}

\begin{abstract}
Abstrak
Penatalaksanaan TB membutuhkan waktu yang lama dan biaya yang besar. Saat ini berbagai RS menentukan tarif berdasarkan metode DD. Perhitungan biaya satuan pada pelayanan kesehatan dapat dilakukan dengan menggunakan metode Activity Based Costing $(A B C)$. Mengetahui perhitungan unit cost dengan metode ABC dan DD di Instalasi Rawat Jalan dan Rawat Inap TB Paru Kategori 2 di RS Paru. Deskriptif analitik menggunakan data sekunder dan metoda Pusposive Sample. Penelitian dilakukan di RS Paru Bandung selama bulan September sampai Desember 2013 menggunakan data rekam medis dalam kurun waktu 2 tahun. Perhitungan biaya satuan dengan metode $\mathrm{ABC}$ untuk pasien rawat jalan sebesar Rp. 611.321; pasien rawat darurat sebesar Rp. 713.852; pasien rawat inap yang masuk melalui instalasi rawat jalan sebesar Rp. 5.037.309 dan pasien rawat darurat sebesar Rp. 4.398.415. Biaya satuan dengan metode DD untuk pasien rawat jalan sebesar Rp. 421.621; pasien rawat darurat sebesar Rp. 734.170; untuk pasien rawat inap yang masuk melalui instalasi rawat jalan sebesar Rp. 1.727.213 dan instalasi rawat darurat sebesar Rp. 1.846.337. Jumlah obat yang diberikan untuk pasien rawat jalan yaitu untuk 2 minggu dan ALOS untuk pasien rawat inap yaitu 9,2 hari. Perhitungan biaya satuan dengan menggunakan metode ABC lebihmenguntungkan secara finansial bagi Rumah Sakit.
\end{abstract}

Kata Kunci : Activity Based Costing, Biaya satuan, Double Distribution

\section{The Differences of Unit Cost Calculation By Activity Based Costing (ABC) Method And Double Distribution (DD) Method For Category 2 of Pulmonary TB Patients in Outpatient and Inpatient Of Lung Hospital}

Abstract

Tuberculosis management requires a long time and a large cost. Currently hospitals determine tariffs based on Double Distribution (DD) Method. But, actually unit cost of health services can also be calculated by Activity Based Costing (ABC) Method, which is based on activities. To determine the unit cost calculation by ABC method and DD Method of Category 2 pulmonary TB in Outpatient and Inpatient Installation of Lung Hospital. Descriptive analytic uses secondary data and Pusposive Sampling methods. The study was conducted at Lung Hospital Bandung during September to December 2013 by using medical records within a period of 2 years. The calculation of the unit costs averages uses the ABC method for category 2 Pulmonary TB patient in outpatient Installation was Rp. 611.321; in emergency care unit was Rp. 713.852; for hospitalized patients that come through the outpatient installation was Rp. 5.037 .309 and through emergency care unit was Rp. 4.398.415. The unit cost averages uses DD methods for category 2 Pulmonary TB in outpatient Installation was Rp. 421.621; in emergency care unit was Rp. 734.170; for hospitalized patient that come through the outpatient installation was Rp. 1.727.213 and through emergency care unit was Rp. 1.846.337. The quantity of drugs given to outpatients is for 2 weeks while ALOS for hospitalized patients is 9.2 days. Unit costs calculation uses ABC method is financially more advantageous for the Hospital than using DD methode.

Keywords: Activity Based Costing, Double Distribution, Unit Cost

Korespondensi :

Lukman Hilfi, dr., MM

Departemen Ilmu Kesehatan Masyarakat Fakultas Kedokteran Universitas Padjadjaran

Jl. Eijkman No. 38 Bandung

Email : lukmanhilv@gmail.com 


\section{Pendahuluan}

Indonesia menduduki rangking ke-5 dari 22 negara-negara yang mempunyai beban tinggi untuk TB dan memberikan kontribusi jumlah kasus TB di dunia sebesar 4,7\%. Penatalaksanaan TB tidak mudah, membutuhkan waktu yang lama dan membutuhkan biaya yang besar. Panduan OAT yang digunakan untuk menanggulangi TB di Indonesia untuk TB Paru kategori 2 diberikan pada pasien kambuh, gagal dan putus (drop out) berobat minimal selama 8 bulan dengan 2 bulan pertama diberi injeksi Streptomicin setiap hari. Kasus drop out pada pengobatan TB Paru Kategori 2 dapat berpotensi berkembang menjadi resistensi obat sekitar 6-29\% ${ }^{1}$. Pada saat ini pembiayaan untuk program penanggulangan TB menjadi tanggung jawab pemerintah pusat, propinsi, kabupaten/kota, dan sumber lain yang sah dan tidak mengikat ${ }^{2}$.

Pada awal tahun 2014, seiring dengan pelaksanaan jaminan kesehatan oleh BPJS yang mencakup penyediaan pelayanan kesehatan dan pembiayaan kesehatan secara menyeluruh, keadaan infrastruktur yang baik di masyarakat menentukan pemerataan pelayanan kesehatan dan jaminan kesehatan sedangkan pembiayaan kesehatan secara menyeluruh berhubungan dengan strategi kebijakan pembiayaan yaitu pembiayaan investasi dan berbagai tindakan medis yang mungkin belum dapat ditutupi oleh BPJS dan besarnya biaya yang harus dibayarkan oleh BPJS kepada Rumah Sakit yang menyangkut besaran tarif jasa medik. Permasalahan lain yang terjadi, penetapan tarif di Rumah Sakit pemerintah dipengaruhi oleh norma dan regulasi pemerintah serta penyusunan tarif di Rumah Sakit belum didasarkan pada perhitungan unit cost sehingga seringkali tarif belum dapat menunjukkan biaya aktual yang dikeluarkan Rumah Sakit secara tepat sebagai pembeli sumber daya. Secara umum masyarakat mengharapkan tarif Rumah Sakit rendah sehingga masyarakat mendapatkan akses yang mudah, akan tetapi tarif yang rendah dengan subsidi yang tidak mencukupi dapat menyebabkan kualitas pelayanan turun dan hal ini menjadi masalah besar untuk manajemen Rumah Sakit ${ }^{3}$.

Salah satu solusi untuk menangani masalah tersebut adalah dengan cara menghitung secara akurat biaya tetap dan biaya variabel yang dikeluarkan oleh Rumah Sakit sehingga didapatkan biaya yang lebih rendah dan kualitas pelayanan yang lebih baik. Selama ini perhitungan unit cost Rumah Sakit hanya menggunakan metode Double Distribution (DD) yang tidak mencerminkan aktivitas yang spesifik karena banyaknya kategori biaya yang bersifat tidak langsung dan cenderung fixed serta lebih berdasarkan kepada perkiraan dan perbandingan dengan tarif Rumah Sakit lain yang sejenis. Perhitungan biaya yang tidak tepat akan memberikan informasi biaya yang tidak tepat pula yaitu undercosting atau overcosting yang dapat mengakibatkan kesalahan pengambilan keputusan. Rumah Sakit mempunyai berbagai macam fasilitas dan jumlah biaya overhead yang tinggi, maka semakin menuntut ketepatan dalam pembebanan biaya yang sesungguhnya ${ }^{4}$. Distorsi dalam penghitungan biaya dapat mengakibatkan kesalahan pengambilan keputusan dalam hal tarif dan kelangsungan pelayanan Rumah Sakit.

Oleh karena itu, diperlukan alternatif sistem penghitungan biaya berdasarkan aktivitas atau lebih dikenal dengan metode Activity Based Costing (ABC) $)^{5}$. Activity Based Costing (ABC) dalam memperhitungkan biaya yang terjadi akan menghasilkan informasi biaya yang akurat karena menggunakan lebih dari satu cost driver. Pada metode ABC, aktivitas merupakan titik pusat dari kegiatan sehingga setiap Rumah Sakit harus mengembangkan suatu Integrated Clinical Pathway yang dituangkan dalam bentuk standar prosedur operasional (SPO) sehingga alur pelayanan pasien lebih jelas ${ }^{6}$.

Informasi mengenai aktivitas yang terdapat dalam integrated clinical pathway akan menjadi data dasar. Metode ABC tidak hanya memperhatikan perhitungan satuan biaya jasa ataupun produk saja tetapi memiliki cakupan yang lebih luas diantaranya yaitu pengurangan biaya yang diperoleh dari pengelolaan aktivitas yang akan sejalan dengan pengendalian biaya. Pengurangan biaya pada metode $\mathrm{ABC}$ dapat dilakukan terhadap seluruh biaya yang terjadi, baik pada bagian awal aktivitas, proses produksi maupun pada tahap akhir dari suatu rangkaian aktivitas sehingga penggunaan Activity Based Costing mampu mengukur secara cermat biayabiaya yang dikeluarkan dari setiap aktivitas untuk menghasilkan tarif yang tepat. Tujuan Penelitian ini yaitu untuk mengetahui perhitungan unit cost dengan metode ABC di Instalasi Rawat Jalan TB Paru Kategori 2 di Rumah Sakit Paru, mengetahui perhitungan unit cost dengan metode DD di Instalasi Rawat Jalan TB Paru Kategori 2 di Rumah Sakit Paru dan mengetahui perhitungan unit cost dengan menggunakan metode $\mathrm{ABC}$ lebih menguntungkan dibandingkan dengan metode DD. Keutamaan penelitian ini adalah unit cost yang didapatkan dengan menggunakan metode ABC akan lebih akurat dan menguntungkan dibandingkan metode Double Distribution (DD) yang selama ini dilakukan di Rumah Sakit Paru, diharapkan dapat menjadi sumber informasi bagi Rumah Sakit, BPJS maupun Kementerian Kesehatan dalam mengevaluasi efisiensi biaya 
Lukman Hilfi : Perbedaan Perhitungan Unit Cost dengan Menggunakan Metode Activity Based Costing (ABC) dan Metode Doubel Distribution (DD) untuk Pasien Tb Paru Kategori 2 di Instalasi Rawat Jalan dan Rawat Inap Rumah Sakit Paru

rawat jalan dan rawat inap pasien TB Paru kategori 2

\section{Metode}

Penelitian ini adalah deskriptif dengan menggunakan data sekunder. Data sekunder diperoleh dari dokumen-dokumen mengenai biaya dan Integrated Clinical Pathway berdasarkan data yang terdapat pada catatan rekam medik yaitu berupa data setiap tindakan yang dilakukan kepada pasien TB paru kategori 2 di Instalasi Rawat Jalan dan Rawat Inap. Setiap aktivitas pasien dari mulai datang sampai dengan pulang yang terdapat pada Integrated Clinical Pathway tersebut menjadi dasar acuan dalam melakukan penghitungan unit cost melalui pendekatan metode Activity Based Costing (ABC) dan metode Double Distribution (DD). Penelitian dilaksanakan di Instalasi Rawat Jalan dan Rawat Inap Rumah Sakit Paru Bandung, dilaksanakan pada bulan Mei sampai dengan November tahun 2014. Populasi pada penelitian ini yaitu data rekam medik seluruh pasien yang telah didiagnosis TB paru Kategori 2 dan memulai pengobatan TB paru kategori 2 pada Januari 2012 sampai dengan Desember 2012. Penarikan sampel menggunakan teknik purposive sampling sedangkan penentuan sample size menggunakan rumus Yamane yaitu sebanyak 49 sampel dengan perhitungan sebagai berikut:

$\mathrm{n}=\frac{97}{1+97 \cdot(0,1)^{2}}=\frac{97}{1,97}=49$

Data sekunder diperoleh dari data rekam medik pasien TB paru kategori 2 kurun waktu 1 tahun yaitu pada bulan Januari 2012 sampai dengan Desember 2012, dokumen standar operasional prosedur (SOP) dan dokumen-dokumen pendukung lainnya. Pada tahap awal kajian akan dilakukan penarikan sampel berdasarkan pada data pasien rawat jalan yang telah menjalani pengobatan TB Paru kategori 2. Selanjutnya berdasarkan nomer rekam medik dan nama pasien pada data pasien, diambil dokumen rekam mediknya. Penelitian ini telah memenuhi kaidah ethical clearance sesuai ketentuan yang berlaku

\section{Hasil}

Berdasarkan clinical pathway pasien TB Paru Kategori 2 yang datang ke RSP Rotinsulu terdapat 4 kelompok yaitu : a. Pasien TB Paru Kategori 2 yang datang ke poliklinik rawat jalan dan menjalani pengobatan rawat jalan berjumlah 4 orang.

b. Pasien TB Paru Kategori 2 yang datang ke poliklinik rawat jalan dan menjalani rawat inap berjumlah 38 orang.

c. Pasien TB Paru Kategori 2 yang datang ke Instalasi Rawat Darurat, mendapatkan pengobatan dan diperkenankan pulang berjumlah 1 orang.

d. Pasien TB Paru Kategori 2 yang datang ke Instalasi Rawat Darurat dan diharuskan menjalani rawat inap berjumlah 6 orang.

\section{Perhitungan Biaya Satuan dengan Activity Based Costing}

Dari 49 pasien yang menjadi responden penelitian, 4 orang pasien rawat jalan mendapatkan pelayanan, diberikan obat untuk 14 hari dan tidak harus dilakukan rawat inap. Biaya berobat pasien TB Paru Kategori 2 yang berbedabeda untuk diagnosa yang sama baik ditinjau dari biaya pengobatan dengan obat maupun tanpa obat. Biaya obat merupakan cerminan dari obat yang diberikan kepada pasien. Obat yang diberikanpun tidak sama antara pasien yang satu dengan pasien lainnya. Responden pasien TB Paru Kategori 2 yang datang ke Rumah Sakit ada yang datang diluar jam buka poliklinik sehingga ditangani di instalasi rawat darurat. Pasien TB Paru Kategori 2 yang datang ke instalasi rawat darurat ada yang boleh pulang dan ada yang harus di rawat. Satu orang pasien yang datang ke instalasi rawat darurat diperbolehkan pulang dan diberikan obat untuk 14 hari ke depan.

Pasien yang terbanyak adalah pasien TB Paru Kategori 2 yang dirawat inap. Pasien rawat inap ini masuk ke Rumah Sakit melalui instalasi rawat jalan. Perhitungan biaya satuan rawat inap ini sudah memperhitungkan biaya rawat jalan dan biaya rawat inapnya sesuai dengan lama hari rawat setiap pasien. Penanganan pasien TB Paru Kategori 2 yang dirawat inap sangat bervariasi, baik dilihat dari lama hari rawat inapnya maupun dari pengobatan yang diberikan. Adapun biaya satuan rawat inap memiliki rentang yang sangat tinggi mulai dari sekitar Rp. 2,9 juta rupiah sampai dengan Rp 11 juta. Hal yang sama juga dapat terlihat pada detail obat yang diberikan untuk setiap pasien dan lama hari rawat masingmasing pasien. Rentang biaya obat pada pasien mulai dari hanya Rp. 13 ribu sampai dengan Rp. 300 ribu. Kondisi yang sama juga terjadi pada pasien rawat inap yang masuk melalui rawat darurat, biaya pengobatan dan variasi penanganan pasien TB Paru Kategori 2 juga terjadi. Biaya satuan rawat inap pasien yang berasal dari rawat darurat memiliki rentang dari $\mathrm{Rp} 2,4$ juta sampai 
Lukman Hilfi : Perbedaan Perhitungan Unit Cost dengan Menggunakan Metode Activity Based Costing (ABC) dan Metode Doubel Distribution (DD) untuk Pasien Tb Paru Kategori 2 di Instalasi Rawat Jalan dan Rawat Inap Rumah Sakit Paru

dengan Rp 6,9 juta, dengan rata-rata Rp 4,3 juta.

Berdasarkan hasil perhitungan biaya satuan pasien TB Paru Kategori 2 dengan menggunakan metode $\mathrm{ABC}$ diperoleh gambaran bahwa penanganan pasien TB tersebut sangat bervariasi pada clinical pathway nya. Perbedaan clinical pathway penanganan pasien TB Paru Kategori 2 tidak hanya terjadi pada dokter yang berbeda, tetapi juga terjadi pada dokter yang sama dengan pasien yang berbeda. Adapun resume dari perhitungan biaya satuan paket pelayanan bagi pasien TB Paru Kategori 2 yang dilayani di rawat jalan, rawat inap maupun rawat darurat dapat dilihat pada tabel 1

Perhitungan Biaya Satuan dengan Metode DD (DD)

Perhitungan biaya satuan dengan

Tabel 1. Interval Biaya Paket Biaya Satuan Pasien TB Paru Kategori 2 Berdasarkan Perhitungan dengan Metode ABC

\begin{tabular}{lccc}
\hline \multicolumn{1}{c}{ Jenis Pelayanan } & Unit Cost Minimal & Unit Cost Maksimal & UC Rata-rata \\
\hline Rawat jalan & 454.888 & 725.907 & 611.321 \\
rawat jalan dan rawat inap & 2.698 .396 & 11.066 .312 & 5.037 .309 \\
Rawat darurat & 713.852 & - & - \\
Rawat darurat dan rawat inap & 2.420 .070 & 6.913 .104 & 4.398 .415 \\
\hline
\end{tabular}

menggunakan metode DD dilakukan dengan mendistribusikan biaya dari unit penunjang ke unit produksi. Tahap pertama biaya dari unit penunjang didistribusikan ke unit penunjang lainnya. Selanjutnya biaya dari unit penunjang hasil distribusi pertama didistribusikan pada unit produksi. Perhitungan biaya satuan dilakukan dengan membagi setiap biaya yang terjadi pada unit produksi yang sudah ditambahkan dengan biaya dari unit penunjang pada tahap distribusi kedua dengan sejumlah luaran pelayanan yang diberikan oleh unit produksi tersebut. Asumsi yang digunakan pada metode DD diataranya yaitu luas lantai untuk distribusi biaya pemeliharaan gedung; jumlah sumber daya manusia berikut pendidikannya untuk distribusi biaya sdm dan biaya administrasi; Porsi makan, seharusnya digunakan untuk distribusi biaya dapur tetapi karena tidak didapatkan data porsi makanan yang diberikan pada pasien pada tahun 2012 maka digunakan jumlah orang hari untuk distribusi biaya dapur; Biaya obat tidak didistribusikan karena dibebankan langsung kepada pasien sesuai dengan jumlah dan jenis obat yang diperoleh pasien.

Untuk dapat diperbandingkan antara biaya satuan pasien TB Paru Kategori 2 dengan menggunakan metode $\mathrm{ABC}$ dan metode $\mathrm{DD}$, maka perhitungan biaya satuan DD juga dapat dihitung dalam bentuk paket pelayanan. Perhitungan dengan metode DD juga dikelompokkan ke dalam 4 kelompok yaitu biaya satuan rawat jalan, biaya satuan pasien rawat darurat, niaya satuan pasien rawat inap yang melalui rawat jalan dan biaya satuan pasien rawat inap yang melalui rawat darurat. Biaya satuan untuk pasien rawat darurat dengan menggunakan metode DD sebesar Rp. 734.170. Nilai ini lebih besar dibandingkan dengan hasil perhitungan biaya satuan dengan metode $\mathrm{ABC}$ untuk rawat darurat, berbeda dengan nilai untuk perawatan di instalasi lainnya yang nilai nya lebih kecil. Adapun resume dari perhitungan biaya satuan paket pelayanan TB Paru Kategori 2 dengan menggunakan metode DD adalah sebagai berikut :

Tabel 2. Interval Biaya Satuan Paket Pelayanan Pasien TB Paru Kategori 2 Berdasarkan Perhitungan dengan Metode DD

\begin{tabular}{lccc}
\hline \multicolumn{1}{c}{ Jenis Pelayanan } & Unit Cost Minimal & Unit Cost Maksimal & UC Rata-rata \\
\hline Rawat jalan & 283.330 & 510.808 & 421.621 \\
rawat jalan dan rawat inap & 1.035 .662 & 3.542 .834 & 1.727 .213 \\
Rawat darurat & 734.170 & - & \\
Rawat darurat dan rawat inap & 1.288 .693 & 2.540 .901 & 1.846 .337 \\
\hline
\end{tabular}


Lukman Hilfi : Perbedaan Perhitungan Unit Cost dengan Menggunakan Metode Activity Based Costing (ABC) dan Metode Doubel Distribution (DD) untuk Pasien Tb Paru Kategori 2 di Instalasi Rawat Jalan dan Rawat Inap Rumah Sakit Paru

Tarif Pelayanan Pasien TB Paru Kategori 2 Penelitian ini juga mencoba melakukan identifikasi besaran biaya yang dibebankan kepada pasien TB Paru Kategori 2 sesuai dengan pengelompokkan yang digunakan untuk menghitung biaya satuan dengan menggunakan metode ABC dan metode DD. Secara operasional Rumah Sakit tidak menerapkan sistem paket pelayanan baik untuk pasien rawat jalan, rawat darurat maupun rawat inap. Penelitian ini melakukan perhitungan paket pelayanan dikarenakan pada implementasi Jaminan Kesehatan Nasional, Rumah Sakit melakukan klaim pembayaran pada BPJS untuk pasien yang dilayani baik rawat inap maupun rawat jalan dengan perhitungan INA-CBGs. Perhitungan INA-CBGs tidak menerapkan pembiayaan pasien atas dasar setiap jenis layanan yang diterima pasien tetapi berdasarkan koding yang telah ditetapkan dan sifatnya berupa paket pelayanan. Adapun resume perhitungan paket pelayanan TB Paru Kategori 2 berdasarkan tarif yang berlaku di Rumah Sakit untuk pasien rawat jalan, rawat inap maupun rawat darurat dapat dilihat pada tabel 3 .
Kesenjangan Biaya Satuan dengan metode ABC, DD dan Tarif

Berdasarkan hasil perhitungan biaya satuan yang dibuat, baik dengan metode $\mathrm{DD}$ maupun dengan $\mathrm{ABC}$, dinilai dengan kesenjangan yang terjadi terhadap tarif yang berlaku. Kesenjangan yang terjadi dapat bersifat positif dapat pula bersifat negatif.

Kesenjangan negatif bila hasil perhitungan biaya satuan lebih besar daripada tarif yang dibebankan pada pasien.Kesenjangan positif terjadi bila tarif yang dibebankan pada pasien lebih besar dibandingkan dengan hasil perhitungan biaya satuan baik dengan menggunakan metode DD maupun metode ABC.

Kesenjangan negatif bila hasil perhitungan biaya satuan lebih besar daripada tarif yang dibebankan pada pasien.Kesenjangan positif terjadi bila tarif yang dibebankan pada pasien lebih besar dibandingkan dengan hasil perhitungan biaya satuan baik dengan menggunakan metode DD maupun metode $\mathrm{ABC}$.

Tabel 3 Interval Paket Pelayanan Pasien TB Paru Kategori 2 Berdasarkan Tarif Pelayanan yang Berlaku

\begin{tabular}{lccc}
\hline \multicolumn{1}{c}{ Jenis Pelayanan } & Tarif minimal & Tarif maksimal & Tarif rat-rata \\
\hline Rawat jalan & 238.393 & 428.819 & 360.393 \\
rawat jalan dan rawat inap & 1.453 .165 & 5.853 .753 & 2.774 .563 \\
Rawat darurat & 427.408 & - & \\
Rawat darurat dan rawat inap & 905.453 & 2.691 .231 & 1.926 .060 \\
\hline
\end{tabular}

Tabel 4 Kesenjangan Antara Biaya Satuan Minimal, Maksimal dan Rata-Rata dengan Metode DD dan Metode ABC Terhadap Tarif Paket Pelayanan

\begin{tabular}{lccccc}
\hline & Rawat Jalan & $\begin{array}{c}\text { Rawat Jalan } \\
\text { dan Rawat } \\
\text { Inap }\end{array}$ & $\begin{array}{c}\text { a w a } \\
\text { Darurat }\end{array}$ & $\begin{array}{c}\text { Rawat } \\
\text { dan Rawat Inap }\end{array}$ \\
\hline $\begin{array}{l}\text { Selisih Biaya Satuan Minimal Metode } \\
\text { DD dengan Tarif Minimal }\end{array}$ & $(44,937.40)$ & $417,502.97$ & $(306,761.94)$ & $(383,239.85)$ \\
\hline $\begin{array}{l}\text { Selisih Biaya Satuan Minimal Metode } \\
\text { ABC dengan Tarif Minimal }\end{array}$ & $(216.495)$ & $(1.245 .231)$ & $(286.444)$ & $(1.514 .617)$ \\
\hline $\begin{array}{l}\text { Selisih Biaya Satuan Maksimal Metode } \\
\text { DD dengan Tarif Maksimal }\end{array}$ & $(81,989.66)$ & $2,313,918.63$ & - & $150,330.06$ \\
\hline $\begin{array}{l}\text { Selisih Biaya Satuan Maksimal Metode } \\
\text { ABC dengan Tarif Maksimal }\end{array}$ & $(297.088)$ & $(5.212 .559)$ & - & $(4.221 .873)$ \\
\hline $\begin{array}{l}\text { Selisih Biaya Satuan Rata-Rata Metode } \\
\text { DD dengan Tarif rata-rata }\end{array}$ & $(61,228.34)$ & $1,047,349.66$ & - & $79,723.08$ \\
\hline $\begin{array}{l}\text { Selisih UC Rata-Rata Metode ABC } \\
\text { dengan Tarif rata-rata }\end{array}$ & $(250.928)$ & $(2.262 .746)$ & - & $(2.472 .355)$ \\
\hline
\end{tabular}


Berdasarkan tabel 4 dapat dilihat bahwa secara keseluruhan tarif yang dibebankan pada pasien lebih kecil dibandingkan dengan hasil perhitungan biaya satuan untuk setiap jenis layanan yang diterima baik dengan menggunakan metode $\mathrm{ABC}$ maupun dengan metode DD. Bila dibandingkan antara tarif dengan biaya satuan yang dihitung, maka yang memiliki kesenjangan postif adalah biaya rawat inap pasien yang datang melalui instalasi rawat jalan yang dihitung dengan metode $\mathrm{DD}$, baik ditinjau dari kesenjangan rata-rata biaya satuan minimal, biaya satuan rata-rata maupun biaya satuan maksimal. Kesenjangan positif lainnya adalah pada biaya pasien rawat inap yang datang melalui instalasi rawat darurat yang ditinjau dari biaya satuan rata-rata dan biaya satuan maksimal.

Hal ini menunjukkan bahwa biaya pelayanan yang dibebankan pada pasien selama ini mengindikasikan Rumah Sakit harus selalu melakukan subsidi biaya, pihak Rumah Sakit harus selalu menyediakan pembiayaan bagi pasien karena kemungkinan pihak manajemen Rumah Sakit tidak memperhitungkan biaya investasi dan biaya operasional pada penetapan tarif pelayanan.

Perhitungan biaya satuan dengan metode $\mathrm{ABC}$ didasar pada aktivitas pelayanan yang diterima pasien atau pada aktivitas yang diberikan oleh pihak Rumah Sakit kepada pasien, sesuai dengan clinical pathway bagi setiap pasien. Perhitungan biaya satuan dengan metode $\mathrm{ABC}$ berbeda dengan metode DD, pada metode DD perhitungan biaya satuan dilakukan dalam 2 tahap. Tahap pertama adalah dengan mendistribusikan seluruh biaya penunjang (pusat biaya) kepada biaya penunjang lainnya. Setelah itu baru dilakukan distribusi kedua yaitu dengan mendistribusikan total biaya penunjang dimasing-masing unit penunjang yang sudah dilakukan distribusi pertama keseluruh pusat pendapatan. Untuk mendapatkan hasil biaya satuan disetiap pusat pendapatan, hasil distribusi kedua dibagi dengan masingmasing luaran dari setiap pusat pendapatan.

\section{Pembahasan}

Berdasarkan hasil perhitungan biaya satuan dengan menggunakan metode $\mathrm{ABC}$ dan metode DD, didapatkan secara umum biaya satuan dengan metode DD lebih mendekati tarif pelayanan yang saat ini diberlakukan oleh Rumah Sakit. Perhitungan dengan metode ABC memberikan hasil jauh lebih besar dibandingkan tarif yang berlaku, hampir mendekati dua kali lipat dari tarif yang berlaku.

Untuk mengetahui apakah pendapatan Rumah Sakit lebih besar dibandingkan biaya produksi, dibutuhkan perhitungan biaya satuan untuk seluruh pelayanan yang diselenggarakan oleh Rumah Sakit. Hal ini disebabkan karena pada metode DD, biaya yang didistribusikan dari pusat biaya penunjang kepada pusat biaya lainnya tidak memandang apakah pasien mendapatkan pelayanan dari unit penunjang tersebut. Sebagai contoh, pasien yang tidak mendapatkan pelayanan laundry, akan terkena beban biaya dari pusat penunjang laundry sebagai hasil dari distribusi pertama. Oleh karena itu untuk mengetahui apakah pendapatan Rumah Sakit dapat menutupi biaya operasional dan mencadangkan biaya untuk investasi ulang perlu dilihat pendapatan Rumah Sakit berdasarkan perhitungan biaya satuan dari seluruh pelayanan yang diberikan.

Perhitungan biaya satuan dengan menggunakan metode $\mathrm{ABC}$, mensyaratkan adanya clinical pathway untuk setiap pelayanan yang diselenggarakan oleh Rumah Sakit. Kesamaan clinical pathway untuk satu jenis pelayanan ditunjukan oleh standar opersional prosedur (SOP). Selain dibutuhkan clinical pathway, juga dibutuhkan komitmen dari para dokter yang memberikan pelayanan untuk mematuhi SOP yang sudah dibuat, termasuk kepatuhan terhadap obat yang diberikan pada pasien, baik pasien rawat jalan, rawat darurat maupun rawat inap. Kepatuhan pemberian obat tersebut, meliputi kepatuhan terhadap jenis obat dan jumlah obatnya. Berdasarkan hasil penelitian didapatkan pasien yang datang mendapatkan obat yang sangat bervariasi. Obat pertama yaitu obat anti Tuberculosis pun diberikan bervariasi.

Pada implementasi Jaminan Kesehatan Nasional (JKN), semakin efisien penggunaan sumber daya di Rumah Sakit akan berdampak pada semakin besarnya biaya yang disisihkan oleh Rumah Sakit, karena INA-CBGs merupakan bentuk klaim yang dilakukan Rumah Sakit pada BPJS yang berbentuk paket pelayanan. Kepatuhan terhadap SOP, penggunaan obat rasional merupakan hal penting agar keseimbangan keuangan Rumah Sakit dapat tetap positif, pendapatan Rumah Sakit lebih besar dibandingkan dengan pengeluaran Rumah Sakit. Pada implementasi JKN, bila pendapatan Rumah Sakit dibandingkan dengan biaya operasional, keseimbangan kas masih menunjukan balans positif tetapi pada saat pendapatan Rumah Sakit dibandingan dengan biaya investasi per tahun dan biaya operasional maka seringkali menunjukan balans yang negatif, sehingga akan sulit bagi pihak manajemen untuk melakukan investasi ulang.

RSP Rotinsulu merupakan Rumah Sakit pemerintah, yang mendapatkan pembiayaan tidak hanya berasal dari pendapatan Rumah Sakit tetapi juga memperoleh biaya yang berasal dari 
Kementrian Kesehatan, dalam bentuk APBN. Kebutuhan investasi ulang dapat dimintakan pada Kementrian Kesehatan. Ditinjau dari sudut manajemen, ketergantungan keuangan pada pihak di luar manajemen Rumah Sakit bukan merupakan hal yang baik. Keterbatasan keuangan pemerintah mengharuskan pemerintah melakukan prioritas dalam perencanaan pembangunan kesehatan, sehingga sangat sulit bagi pemerintah untuk dapat memenuhi seluruh kebutuhan anggaran bagi seluruh Rumah Sakit milik pemerintah. Pihak manajemen Rumah Sakit secara betahap perlu mengurangi ketergantungan keuangan pada pemerintah walaupun Rumah Sakit tersebut milik pemerintah. Hal ini dapat dilakukan bila pendapatan Rumah Sakit mampu menutupi biaya investasi ulang. Berdasarkan perhitungan biaya satuan metode $\mathrm{ABC}$, setiap aktivitas yang diberikan kepada pasien dihitung pembiayaannya. Hal ini menyebabkan hasil perhitungan biaya satuannya jauh lebih besar dibandingkan dengan metode DD maupun tarif yang berlaku. Kondisi ini menyiratkan sebenarnya cukup banyak aktivitas yang diterima oleh pasien yang diberikan oleh manajemen Rumah Sakit yang tidak dibebankan biayanya. Sebagai contoh, berdasarkan tabel 4 , rata-rata biaya satuan untuk pasien rawat inap dibandingkan dengan tarif didapatkan selisih Rp 2 juta sampai dengan Rp 2,5 juta. Bila terdapat 49 pasien dalam setahun, selisih antara tarif dan perhitungan biaya satuan mendekati Rp 100 juta pasien per tahunnya. Nilai tersebut baru dari satu jenis pelayanan. Bila seluruh pelayanan dihitung dengan metode $\mathrm{ABC}$, maka selisih ini akan jauh lebih besar. Penjumlahan dari seluruh selisih perhitungan tersebut untuk semua jenis pelayanan yang diselenggarakan oleh Rumah Sakit, mengindikasikan potensi pendapatan yang dapat diraih oleh Rumah Sakit.

Di pihak lain besarnya hasil perhitungan biaya satuan dengan metode $\mathrm{ABC}$ maupun metode $\mathrm{DD}$, dapat memberatkan pasien sehingga pasien TB Paru Kategori 2 tidak dapat menuntaskan pengobatannya. Pasein TB Paru Kategori 2 yang tidak tuntas pengobatannya merupakan sumber penularan bagi anggota keluarganya dan masyarakat sekitarnya. Oleh karena itu perlu dipikirkan solusi yang baik yang dapat mengakomodasi kebutuhan biaya berobat pasien dan kebutuhan pengembangan Rumah Sakit. Upaya-upaya tersebut antara lain, dengan melakukan survey kemampuan membayar / Ability To Pay (ATP) dan kemauan membayar / Willingness To Pay (WTP) pasien terhadap biaya yang dibebankan. Dengan melakukan survey ATP dan WTP, pihak manajemen Rumah Sakit dapat menentukan sebenarnya berapa biaya yang dapat diterima oleh pasien TB Paru Kategori 2 agar pasien dapat teratur menjalani pengobatan sampai tuntas. Apabila hasil ATP dan WTP nya lebih kecil dari perhitungan biaya satuan maka pihak manajemen Rumah Sakit perlu memikirkan sumber biaya lainnya untuk menutupi kekurangan tersebut. Upaya lainnya adalah setiap pasien yang berobat dengan membayar secara fee for service, dianjurkan untuk menjadi peserta JKN dengan mendaftarkan diri ke BPJS sehingga besarnya biaya pelayanan tidak menjadi kendala bagi pasien untuk teratur berobat dan menjalani pengobatannya sampai tuntas. Bila seluruh pasien yang datang berobat sudah menjadi peserta BPJS, maka pihak manajemen Rumah Sakit sebaiknya melakukan penataan internal Rumah Sakit dalam bentuk efisiensi operasional Rumah Sakit, kepatuhan terhadap SOP yang telah disepakati bersama dan pengunaan obat yang rasional serta pemeriksaan laboratorium yang sesuai dengan kebutuhan pasien yang hasilnya dapat membantu dokter dalam menentukan diagnosa, menentukan pengobatan maupun menentukan tingkatan penyakit dan komplikasinya.

Kesimpulan pada penelitian ini yaitu bahwa perhitungan biaya satuan dengan menggunakan metode $\mathrm{ABC}$ lebih menguntungkan secara finansial bagi Rumah Sakit dibandingkan dengan metode DD. Diharapkan manajemen Rumah Sakit perlu meningkatkan kerapihan pencatatan pelaporan baik keuangan, pelayanan, dan data investaris. Data-data tersebut sangat penting untuk meningkatkan keakuratan perhitungan unit cost yang dijadikan dasar penentuan tarif pelayanan Rumah Sakit; perlu membuat standar operasional prosedur untuk seluruh pelayanan yang diberikan oleh Rumah Sakit mengacu pada kasus-kasus yang datang ke Rumah Sakit; perlu melakukan evaluasi berkala mengenai kepatuhan petugas terhadap SOP yang sudah ditetapkan dan penggunaan obat rasional pada berbagai kasus baik rawat jalan, rawat inap dan rawat darurat demi mengoptimalkan efisiensi Rumah Sakit.

\section{Daftar Pustaka}

1. Burhan, Erlina. Peran ISTC dalam Pencegahan MDR. Departemen Pulmonologi \& Ilmu kedokteran Respirasi FKUI-RS Persahabatan. Vol 7. Jakarta: Jurnal Tuberkulosis Indonesia; 2010.

2. Menkes RI. Peraturan Menteri Kesehatan Republik Indonesia Nomor 13 Tahun 2013 Tentang Pedoman Manajemen Terpadu Pengendalian Tuberkulosis Resistan Obat. Jakarta: Kemenkes RI; 2013.

3. Adisasmita, Wiku. Kebijakan Standar Pelayanan Medik dan Diagnosis Related 
Group (DRG), Kelayakan Penerapannya di Indonesia. Depok: Fakultas Kesehatan Masyarakat Universitas Indonesia; 2008.

4. Budiman, Riadi. Implementasi Metode Activity-Based Costing System dalam menentukan Besarnya Tarif Jasa Rawat Inap (Studi Kasus di RS XYZ). Jurnal ELKHA Vol.4, No 2. Jurusan Teknik Elektro, Fakultas Teknik Universitas Tanjung Pura; 2012.

5. Semiarty dkk. Metode Activity Based Costing Sebagai Penentuan Tarif Rawat Inap Di RSJ Puti Bungsu. Program Pascasarjana Universitas Andalas; 2011.

6. Menkes RI. Peraturan Menteri Kesehatan Republik Indonesia Nomor 12 Tahun 2013 Tentang Pola Tarif Badan Layanan Umum Rumah Sakit Di Lingkungan Kementerian Kesehatan; 2013.

7. Mog yorosy Zsolt, Smith Peter. Literature
Review: The main methodological issues in costing health care services. York: University of York, Centre For Health Economic (CHE); 2005. 8. Kuchta Dorota, Ząbek Sabina. Activitybased costing for health care institutions. 8 th International Conference on Enterprise Systems, Accounting and Logistics (8 th ICESAL 2011). Greece: Thassos Island; 2011.

9. Thabrany, Hasbullah. Penetapan dan Simulasi Tarif Rumah Sakit. Jurnal Manajemen \& Administrasi Rumah Sakit Indonesia. No.1 Vol.1. Depok. 1999.

10. Soepandi, P Z. Diagnosis Dan Faktor Yang Mempengaruhi Terjadinya TB-MDR. Jurnal Tuberkulosis Indonesia. Vol 7. Jakarta: Departemen Pulmonologi \& Ilmu kedokteran Respirasi FKUI-RS Persahabatan; 2010. 